\title{
Impact of calcineurin inhibitors on rat glioma cells viability
}

\author{
Jeong Hun Seong ${ }^{1,2}$, Woo Yeong Park ${ }^{1,2}$, Jin Hyuk Paek ${ }^{1,2}$, Sung Bae Park ${ }^{1,2}$, Seungyeup Han ${ }^{1,2}$, Kyo-Cheol Mun ${ }^{3}$, \\ KyubokJin ${ }^{1,2}$
}

\author{
${ }^{1}$ Department of Internal Medicine, Keimyung University School of Medicine, Daegu, Korea \\ ${ }^{2}$ Keimyung University Kidney Institute, Keimyung University School of Medicine, Daegu, Korea \\ ${ }^{3}$ Department of Biochemistry, Keimyung University School of Medicine, Daegu, Korea
}

Received: November 16, 2018

Revised: January 9, 2019

Accepted: January 16, 2019

Corresponding author:

Kyubok Jin

Department of Internal Medicine,

Keimyung University School of

Medicine; Keimyung University

Kidney Institute, Keimyung

University School of Medicine,

56, Dalseong-ro, Jung-gu, Daegu

41931, Korea

Tel: +82-53-250-7399

Fax: +82-53-253-7976

E-mail: mdjin922@gmail.com
Background: Although kidney transplantation outcomes have improved dramatically after using calcineurin inhibitors (CNIS), CNI toxicity continues to be reported and the mechanism remains uncertain. Here, we investigated the neurotoxicity of CNls by focusing on the viability of glioma cells.

Methods: Glioma cells were treated with several concentrations of CNls for 24 hours at $37^{\circ} \mathrm{C}$ and their cell viability was evaluated using 3-(4,5-dimethylthiazol-2-yl)-2,5-diphenyltetrazolium bromide assay.

Results: Exposure to $0,0.25,0.5,2.5,5.0$, and $10.0 \mathrm{mM}$ concentrations respectively showed $100 \%$, $64.3 \%, 61.3 \%, 68.1 \%, 62.4 \%$, and $68.6 \%$ cell viability for cyclosporine and $100 \%, 38.6 \%, 40.8 \%$, $43.7 \%, 37.8 \%$, and $43.0 \%$ for tacrolimus. The direct toxic effect of tacrolimus on glioma cell viability was stronger than that of cyclosporine at the same concentration.

Conclusion: CNIs can cause neurological side effects by directly exerting cytotoxic effects on brain cells. Therefore, we should carefully monitor the neurologic symptoms and level of CNIs in kidney transplant patients.

Keywords: Calcineurin inhibitors; Glioma cell; Kidney transplantation; Neurotoxicity

\section{Introduction}

The results of kidney transplantation (KT) have improved dramatically after the use of calcineurin inhibitors (CNIs) [1]. However, some complications of CNIs have been also reported [2]. Nephrotoxicity was a majorly reported side effect of CNIs that were assessed through laboratory or allograft biopsy findings [3,4]; however, it could be mitigated by controlling $\mathrm{CNI}$ trough levels. Unfortunately, mild neurologic symptoms of CNI neurotoxicity, such as tremors, agitation, insomnia, anxiety, and paresthesia, could easily go unnoticed [5,6]. In such cases, mild symptoms could worsen to cortical blindness, seizures, and encephalopathy, which could cause lethal damage to the brain. Recently, CNI neurotoxicity was diagnosed in computed tomography and magnetic resonance imaging studies, which showed morphological findings such as hypodensity of the white matter, cerebral edema, metabolic encephalopathy, and hypoxic damages [7-9]. Paradoxically, cyclosporine has been found to protect the brain from ischemia-reperfusion injury in animal models; however, the mechanism of CNI neurotoxicity is not yet fully understood.

Here, we investigated the neurotoxicity of two CNIs, cyclosporine, and tacrolimus, on the viability of glioma cells.

\section{Materials and methods}

\section{Cell culture}

Rat glioma cells (Korean Cell Line Bank, Seoul, Korea) were 
cultured in Dulbecco's modified Eagle's medium (WelGENE, Daegu, Korea) supplemented with $10 \%$ fetal bovine serum (WelGENE) and 1\% penicillin-streptomycin (HyClone, Logan, UT, USA). Cells were grown in 10-cm diameter culture plates at $37^{\circ} \mathrm{C}$ under humidified conditions containing $5 \% \mathrm{CO}_{2} / 95 \%$ air.

\section{Measuring the viability of glioma cells}

Cytotoxicity was estimated by the 3-(4,5-dimethyl-thiazol-2yl)-2,5-diphenyl-tetrazolium bromide (MTT) assay, which is based on the cleavage of a tetrazolium salt by mitochondrial dehydrogenases in viable cells. Glioma cells were plated in a 96-well plate at an initial density of 104 cells/well. After 24 hours, the medium was replaced with fresh medium containing various concentrations $(0,0.25,0.5,2.5,5.0$, and $10.0 \mathrm{mM})$ of cyclosporine (Novartis Pharma AG, Basel, Switzerland) or tacrolimus (Fujisawa Pharmaceutical Co., Ltd., Osaka, Japan). The drugs were dissolved in dimethyl sulfoxide, and in the experiment, the cells were diluted in DMEM medium and treated with the required concentrations. Cells were incubated at $37^{\circ} \mathrm{C}$ for 24 hours. During the last 4 hours, the cells were incubated with $20 \mu \mathrm{L}$ of MTT stock solution $(5 \mathrm{mg} / \mathrm{mL})$. The plates were shaken for 10 to 15 minutes in the dark. The optical density was measured at $570 \mathrm{~nm}$ using the microplate reader 550 (Bio-Rad, Lab., Hercules, CA, USA), and the relative cell viability was expressed using the following equation:

$$
\text { Cell viability }(\%)=\mathrm{OD}_{\text {sample }} / \mathrm{OD}_{\text {control }} \times 100
$$

\section{Statistical analysis}

The values are expressed as mean \pm standard deviation. Statistical evaluation of the significant difference between the means was performed using Student's $t$-test. SPSS version 18.0 (SPSS Inc., Chicago, IL, USA) was used for all statistical analyses. $p<0.05$ was considered to be significant.

\section{Results}

Substantial morphological changes were observed in glioma cells when they were treated with cyclosporine or tacrolimus.

The cells were observed at a magnification of $\times 400$ using the DMil inverted microscope (Leica Microsystems, Wetzlar, Germany). Cells were detached and floated to the top of the culture dish; however, a monolayer was not formed (Fig. 1).

For cyclosporine, cell viabilities were as follows: $100 \pm 0.1 \%$ at $0 \mathrm{mM} / \mathrm{L}$ cyclosporine control, $64.3 \pm 18.5 \%$ ( $p<0.05$ vs. control) at $0.25 \mathrm{mM} / \mathrm{L}$ cyclosporine, $61.3 \pm 12.0 \%$ ( $p<0.01$ vs. control) at $0.50 \mathrm{mM} / \mathrm{L}$ cyclosporine, $68.1 \pm 18.8 \%$ ( $p<0.05$ vs. control) at $2.5 \mathrm{mM} / \mathrm{L}$ cyclosporine, $62.4 \pm 24.5 \%$ ( $p<0.05$ vs. control) at

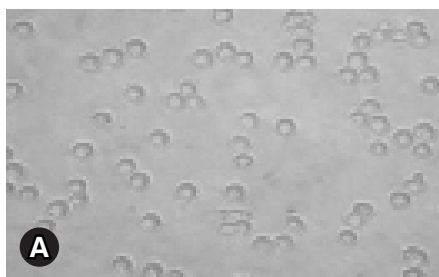

(E)

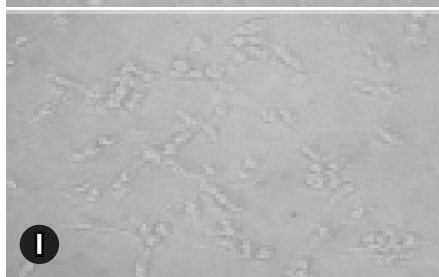

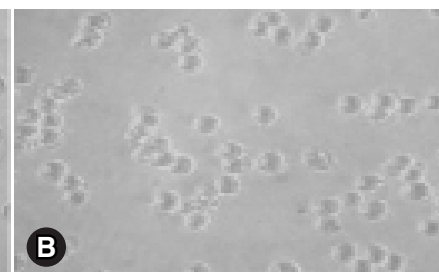

c

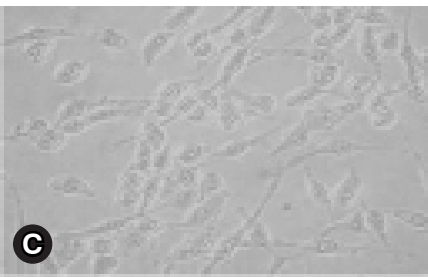

(D)

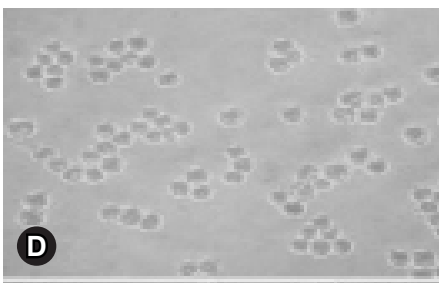

(H)

\section{G}

(

Fig. 1. Comparison of morphological changes and cell viability in glioma cells according to the concentration of cyclosporine or tacrolimus by DMi1 inverted microscopic examination. (A) $0 \mathrm{mM} / \mathrm{L}$ cyclosporine, (B) $0 \mathrm{mM} / \mathrm{L}$ tacrolimus, (C) $0.25 \mathrm{mM} / \mathrm{L}$ cyclosporine, (D) $0.25 \mathrm{mM} / \mathrm{L}$ tacrolimus, (E) $0.5 \mathrm{mM} / \mathrm{L}$ cyclosporine, (F) $0.5 \mathrm{mM} / \mathrm{L}$ tacrolimus, (G) $2.5 \mathrm{mM} / \mathrm{L}$ cyclosporine, (H) $2.5 \mathrm{mM} / \mathrm{L}$ tacrolimus, (I) 5.0 $\mathrm{mM} / \mathrm{L}$ cyclosporine, $(J) 5.0 \mathrm{mM} / \mathrm{L}$ tacrolimus, $(\mathrm{K}) 10.0 \mathrm{mM} / \mathrm{L}$, and (L) $10.0 \mathrm{mM} / \mathrm{L}$ tacrolimus (original magnification, $\times 400$ ). 
$5.0 \mathrm{mM} / \mathrm{L}$ cyclosporine, and $68.6 \pm 19.5 \%$ ( $p<0.05$ vs. control) at $10.0 \mathrm{mM} / \mathrm{L}$ cyclosporine.

For tacrolimus, cell viabilities were as follows: $100 \pm 0.1 \%$ at 0 $\mathrm{mM} / \mathrm{L}$ tacrolimus control, $38.6 \pm 29.4 \%$ ( $p<0.05$ vs. control) at $0.25 \mathrm{mM} / \mathrm{L}$ tacrolimus, $40.8 \pm 26.5 \%$ ( $p<0.05$ vs. control) at 0.50 $\mathrm{mM} / \mathrm{L}$ tacrolimus, $43.7 \pm 21.7 \%$ ( $p<0.05$ vs. control) at $2.5 \mathrm{mM}$ / $\mathrm{L}$ tacrolimus, $37.8 \pm 27.7 \%$ ( $p<0.01$ vs. control) at $5.0 \mathrm{mM} / \mathrm{L}$ tacrolimus, and $43.0 \pm 29.8 \%$ ( $p<0.05$ vs. control) at $10.0 \mathrm{mM} / \mathrm{L}$ tacrolimus.

Our study showed that the direct toxic effect of tacrolimus was stronger on brain cells than that of cyclosporine at the same concentration; however, no significant difference was observed between the two groups.

\section{Discussion}

Although advances in immunosuppressants have resulted in remarkable improvements with respect to allograft acceptance and patient survival rates in KT [1], the use of CNIs, such as cyclosporine and tacrolimus, has caused several side effects including nephrotoxicity [4], post-transplant bone disease [10], hepatotoxicity [11], hypertension [12], diabetes [13], dyslipidemia [2], and neurological side effects $[14,15]$.

The clinical characteristics and mechanisms of CNI neurotoxicity are still controversial and poorly understood. Recently, hypomagnesemia [16], hypocholesterolemia [17], severe vasoconstriction [17], and hypertension via the inhibition of nitric oxide production were reported as precipitating factors [18]; however, they do not sufficiently explain the mechanism of CNI neurotoxicity. In our previous study, cyclosporine and tacrolimus were shown to exhibit cytotoxic effects on renal cells and osteoblasts $[10,19,20]$. Thus, cyclosporine and tacrolimus may also exhibit cytotoxic effects on brain cells. Here, we studied the direct cytotoxicity of cyclosporine and tacrolimus on glioma cell viability to understand the underlying mechanisms of neurotoxicity.

Our results demonstrated that treatment with cyclosporine and tacrolimus resulted in substantial morphological changes as well as cell death in glioma cells.

Although neurotoxicity is known to be frequently associated with CNI trough levels exceeding recommended levels, it also occurs during long-term treatment even when CNI concentrations are within the therapeutic target range. Toxicity may be also be related to the type and dose of CNIs. For instance, tacrolimus is well known to be more potent than cyclosporine. In our study, the direct toxic effect of tacrolimus on glioma cell viability was greater than that of cyclosporine at the same concentration; however, no significant difference was observed. The clinical predisposition and mechanisms of cyclosporine-induced neurotoxicity remain controversial and poorly understood. Further studies are needed to investigate the precipitating factors for CNI-induced central nervous system abnormalities in addition to elucidating the positive effects of CNIs.

Interestingly, cyclosporine was previously reported to improve cerebral ischemia-reperfusion injury in vivo, and low concentrations of cyclosporine were shown to be neuroprotective [21]. Contrastingly, high concentrations of cyclosporine can cause mitochondrial dysfunction, which can lead to the deterioration of energy production, increased oxidative stress [22], and rapid apoptotic or necrotic cell death. Therefore, properly controlling CNI concentrations will be important in preventing CNI neurotoxicity.

CNIs can cause neurological side effects via direct cytotoxic effects in rat glioma cells. Therefore, we should carefully monitor neurologic symptoms and levels of CNIs.

\section{Conflicts of interest}

No potential conflicts of interest relevant to this article was reported.

\section{ORCID}

Jeong Hun Seong, https://orcid.org/0000-0002-5754-1970 Woo Yeong Park, https://orcid.org/0000-0003-2662-2898 Jin Hyuk Paek, https://orcid.org/0000-0001-8875-1260 Sung Bae Park, https://orcid.org/0000-0003-1189-9923 Seungyeup Han, https://orcid.org/0000-0002-7561-6534 Kyo-Cheol Mun, https://orcid.org/0000-0002-7882-6174 Kyubok Jin, https: / / orcid.org/0000-0002-7836-8863

\section{References}

1. Pascual M, Theruvath T, Kawai T, Tolkoff-Rubin N, Cosimi AB. Strategies to improve long-term outcomes after renal transplantation. N Engl J Med 2002;346:580-90.

2. Malvezzi P, Rostaing L. The safety of calcineurin inhibitors for kidney-transplant patients. Expert Opin Drug Saf 2015;14:153146.

3. Burdmann EA, Andoh TF, Yu L, Bennett WM. Cyclosporine nephrotoxicity. Semin Nephrol 2003;23:465-76.

4. Naesens M, Kuypers DR, Sarwal M. Calcineurin inhibitor nephrotoxicity. Clin J Am Soc Nephrol 2009;4:481-508. 
5. Anghel D, Tanasescu R, Campeanu A, Lupescu I, Podda G, Bajenaru O. Neurotoxicity of immunosuppressive therapies in organ transplantation. Maedica (Buchar) 2013;8:170-5.

6. Senzolo M, Ferronato C, Burra P. Neurologic complications after solid organ transplantation. Transpl Int 2009;22:269-78.

7. Besenski N, Rumboldt Z, Emovon O, Nicholas J, Kini S, Milutinovic J, et al. Brain MR imaging abnormalities in kidney transplant recipients. AJNR Am J Neuroradiol 2005;26:2282-9.

8. Coley SC, Porter DA, Calamante F, Chong WK, Connelly A. Quantitative MR diffusion mapping and cyclosporine-induced neurotoxicity. AJNR Am J Neuroradiol 1999;20:1507-10.

9. Schwartz RB, Bravo SM, Klufas RA, Hsu L, Barnes PD, Robson CD, et al. Cyclosporine neurotoxicity and its relationship to hypertensive encephalopathy: CT and MR findings in 16 cases. AJR Am J Roentgenol 1995;165:627-31.

10. Oh YL, Han SY, Mun KH, Choi HJ, Kim HY, Hwang EA, et al. Cyclosporine-induced apoptosis in osteosarcoma cells. Transplant Proc 2006;38:2237-9.

11. Han SY, Chang EJ, Choi HJ, Nam SI, Lee NH, Kwak CS, et al. Total antioxidant status and oxygen free radicals during hepatic regeneration. Transplant Proc 2006;38:2214-5.

12. Hoorn EJ, Walsh SB, McCormick JA, Zietse R, Unwin RJ, Ellison DH. Pathogenesis of calcineurin inhibitor-induced hypertension. J Nephrol 2012;25:269-75.

13. Chakkera HA, Mandarino LJ. Calcineurin inhibition and newonset diabetes mellitus after transplantation. Transplantation 2013;95:647-52.

14. Rosendal F, Bjarkam CR, Larsen M, Hansen HE, Madsen
M, Sørensen JC, et al. Does chronic low-dose treatment with cyclosporine influence the brain? A histopathological study in pigs. Transplant Proc 2005;37:3305-8.

15. Kiemeneij IM, de Leeuw FE, Ramos LM, van Gijn J. Acute headache as a presenting symptom of tacrolimus encephalopathy. J Neurol Neurosurg Psychiatry 2003;74:1126-7.

16. Thompson CB, June CH, Sullivan KM, Thomas ED. Association between cyclosporin neurotoxicity and hypomagnesaemia. Lancet 1984;2:1116-20.

17. Gijtenbeek JM, van den Bent MJ, Vecht CJ. Cyclosporine neurotoxicity: a review. J Neurol 1999;246:339-46.

18. Kou R, Greif D, Michel T. Dephosphorylation of endothelial nitric-oxide synthase by vascular endothelial growth factor. Implications for the vascular responses to cyclosporin A. J Biol Chem 2002;277:29669-73.

19. Han SY, Mun KC, Choi HJ, Kwak CS, Bae JH, Suh SI, et al. Effects of cyclosporine and tacrolimus on the oxidative stress in cultured mesangial cells. Transplant Proc 2006;38:2240-1.

20. Jang YH, Lee YC, Park NH, Shin HY, Mun KC, Choi MS, et al. Polyphenol (-)-epigallocatechin gallate protection from ischemia/reperfusion-induced renal injury in normotensive and hypertensive rats. Transplant Proc 2006;38:2190-4.

21. Folbergrová J, Li PA, Uchino H, Smith ML, Siesjö BK. Changes in the bioenergetic state of rat hippocampus during $2.5 \mathrm{~min}$ of ischemia, and prevention of cell damage by cyclosporin A in hyperglycemic subjects. Exp Brain Res 1997;114:44-50.

22. Beal MF. Mitochondrial dysfunction in neurodegenerative diseases. Biochim Biophys Acta 1998;1366:211-23. 